\title{
Potential mother-to-fetus transmission of SARS-CoV-2: a case report
}

\author{
Yanhui $\mathrm{Li}^{1}$, Zhishan $\mathrm{Jin}^{1}$, and Hongbo Wang ${ }^{1}$ \\ ${ }^{1}$ Wuhan Union Hospital
}

April 28, 2020

\section{Introduction}

The coronavirus disease 2019 (COVID-19) first outbreak at the end of 2019 in Wuhan, China, and quickly spread into more than 200 countries worldwide, turning into a global pandemic. As a new emerging and severe contagious disease, all people are vulnerable to it. Therefore, it's not surprising that more and more pregnant patients are being reported. ${ }^{1,2}$ The maternal and fetus outcomes of COVID-19 pregnant women are the focus of our attention. Fortunately, based on the results of current studies, the clinical characteristic and outcomes of COVID-19 maternal patients are similar to that of non-pregnant women. No maternal death has been reported. ${ }^{1,2}$ But the consequences of infection with SARS-CoV-2 for fetus or newborn are uncertain; especially, there is still huge controversy regarding whether SARS-CoV-2 can be transplacentally transmitted from infected pregnant women to their fetuses. A previous review, through analyzing a total of 38 pregnant women with COVID-19 in China, didn't found intrauterine transmission of SARS-CoV-2. ${ }^{2}$ However, a recent study by L Dong et $\mathrm{al}^{3}$ described a newborn born to a COVID-19 mother with elevated IgM antibody level to SARS-CoV-2, indicating a possible transplacental transmission.

Here, we reported a newborn born to a convalescent COVID-19 mother has a viral pneumonia on the day of birth and elevated IgM/IgG antibody levels to SARS-CoV-2 at 3 days age.

\section{Case}

The mother of the neonatal patient is a 24-year-old healthy primiparous women. At about 1:00 am On March 6, 2020, the pregnant women (at $40^{+4}$ weeks' gestational age) reported a sudden leakage of watery fluid from the vagina. She presented to an emergency department and was diagnosed as "Premature Rupture of Membranes". Because the patient is a citizen of Wuhan city, the epicenter of coronavirus disease-2019 (COVID-19) outbreak, she was underwent chest computed tomography (CT) as routine pre-hospital examinations. The CT scan showed a small size of ground-glass opacities in the left lower lobes, indicating the possibility of the convalescent phase of viral pneumonia. On March 7, the pregnant women was referred to Wuhan Union hospital, a designated hospital for COVID-19 patient. On admission, the patient disclosed that she ever had fever for 2 days at the end of January 2020 (temperature <38), but never had any other symptom such as cough, sputum, myalgia or diarrhea. After orally took azithromycin by herself, body temperature returned to normal and no coronavirus related test was performed.

On admission, physical examination revealed a body temperature 37, pulse of 98 beats per minute, blood pressure of $114 / 68 \mathrm{mmHg}$, respiratory rate of 22 breaths per minute and oxygen saturation of $98 \%$ (breathing ambient air). Lung auscultation revealed no abnormality. Vaginal examination revealed that fetal present descent was at -3, cervix didn't dilate, and amniotic fluid was II-III degree of fecal contamination. Non-stress test was nonreactive. She was diagnosed as "PROM, Fetal distress, Suspected COVID-19 patient".

The pregnant woman underwent emergency cesarean delivery at $5 \mathrm{pm}$ on March 7 in a negative-pressure operating room. A $3800 \mathrm{~g}$ healthy female infant was delivered without complications. Apgar scores at 1 
and 5min were 7 and 9 respectively. Gross inspection of the umbilical cord and placenta didn't show any abnormality. Cord blood retained during the operation was negative for nucleic acid and IgM antibody to SARS-CoV-2, but positive for IgG antibody to SARS-CoV-2. After birth, the infant had no moaning or spitting. Her skin was ruddy and she cried loudly. The mother had been wearing a surgical mask throughout the operation, and the infant had no contact with the mother. The infant was transferred to the neonatology department of Wuhan Women and Children's medical care center for isolation and close observation.

After delivery, 4 repeat oropharyngeal swabs were samples from the maternal patient from March 8 to March 14, all were negative for SARS-CoV-2 RNA by RT-PCR. However, 3 repeat serum IgM and IgG antibody to SARS-CoV-2 were analyzed from March 6 to March 14, all of the test results showed that IgM antibody was negative, and IgG antibody was positive. The maternal patient stayed in the hospital for 9 days. During the hospitalization, she never reported fever, cough, diarrhea or dyspnea, and her blood oxygen saturation maintained at $>95 \%$. After the second chest CT obtained On March 16 showed no abnormalities, the maternal patient was discharged but further quarantined in an isolation site for 14 days.

On admission into the neonatology department, the neonatal case was immediately underwent a Chest CT scan, which showed bilateral pulmonary interstitial emphysemas, indicating the possibility of viral pneumonia. 3 repeat oropharyngeal swabs were collected from March 8 to March 10, and all of the test results were negative for SARS-CoV-2 RNA. On March 10, a first test of serum antibodies to SARS-CoV-2 was underwent and showed that IgM level was $19.26 \mathrm{AU} / \mathrm{ml}$ and IgG level was $107.88 \mathrm{AU} / \mathrm{ml}($ both normal rangej $10 \mathrm{AU} / \mathrm{ml}$ ). However, the neonate nerve had fever, cough, vomiting, feeding difficulties or dyspnea. She was closely monitored in isolation unit and no special treatment was given. A second Chest CT was obtained on March 16, and show all of lesions nearly disappeared. Anti-SARS-CoV-2 IgM decreased to normal level $(6.71 \mathrm{AU} / \mathrm{ml})$, while anti-SARS-CoV-2 IgG level was still elevated $(100.91 \mathrm{AU} / \mathrm{ml})$ on March 24 (Table 1 ). Because her parents were still isolated, the neonate stayed in the hospital until March 30, 2020. So far, the neonate is healthy and breastfeed at home.

\section{DISCUSSION}

As a new emerging and highly pathogenic coronaviruse, the transmission routes of SARS-CoV-2 have not been fully elucidated. Especially, there is a huge controversy regarding whether SARS-CoV-2 can be transplacentally transmitted from infected mothers to their fetuses. DA Schwartz ${ }^{2}$ ever reviewed a total of 38 pregnant women with COVID-19 and didn't found any evidence that SARS-CoV-2 was able to undergoe intrauterine or transplacental transmission. However, a neonatal case with pharyngeal swabs testing positive by RT-PCR at 36 hours age was reported in China, but the results of nucleic acid test of cord blood and placenta in this case are negative, which do not support the diagnosis of intrauterine transmission. ${ }^{4}$ Soon afterwards, L Dong et $\mathrm{al}^{3}$ reported a neonatal case, with elevated IgM/IgG antibodies to SARS-CoV-2 and abnormal cytokine test results, born to a COVID-19 mother at 2 hours of age, indicating the possibility of vertical transmission in utero.

The neonatal case in our report had a manifestation of viral pneumonia in chest $\mathrm{CT}$ on the day of birth and an elevated IgM level at 3 days age. IgM provides the first line of defense during viral infections, prior to the generation of adaptive, high affinity IgG response that is important for long term immunity and immunological memory. ${ }^{5}$ Because IgM antibodies usually do not appear until 3 to 7 days after infection and IgM can't be transferred to the fetus through placenta, the elevated serum IgM in our neonatal case indicates the possibility of vertical transmission in the utero. The date on which the mother of the neonatal case infected with SARS-CoV-2 is uncertain. According to the disclosed history, the results of serum IgG/IgM level and chest CT results, we speculate that the pregnant women was already in the recovery period on admission. Thus, the fetus could have been exposed for the risk of SARS-CoV-2 infection throughout the COVID-19 course of the mother. The slightly increased IgM level and the significantly increased IgG level of the neonatal case are also consistent with the serum characteristics of infected patient in recovery period, which may explain that 3 repeat oropharyngeal swab test was negative for SARS-CoV-2 in the neonate. Of note, because the placenta and amniotic fluid were not collected and detected for SARS-CoV-2 RNA, a direct evidence for intrauterine transmission is still lack in our case report. 


\section{CONCLUSIONS}

The neonatal case in our report, with an elevated IgM level and a manifestation of viral pneumonia in chest $\mathrm{CT}$, highlights the possibility of transplacental transmission from the infected mothers to their fetuses. We suggest that all COVID-19 pregnant women should be closely monitored during pregnancy, and a careful examination of the neonate born to an infected mother should be performed to provide more information about vertical transmission of SARS-CoV-2.

Acknowledgements

We thank the mother of the neonatal case and her family for their cooperation in our study.

Disclosure of interests

None. Completed disclosure of interest forms are available to view online as supporting information.

Contribution to authorship

Y.L., Z.S., and H.W. participated in the design and plan of the study. Y.L. and Z.S. contributed to the data collection. Y.L. and H.W. drafted the manuscript. Y.L. and H.W. revised the manuscript critically. All authors read and approved the final manuscript.

Details of ethical approval

No ethical approval was sought, but written consent to

publish was obtained from the patient

Details of ethical approval

No ethical approval was sought, but written consent to publish was obtained from the patient

Funding

This work was supported by the National Natural Science Foundation of China (grant number 81701423).

\section{References}

1. Chen H, Guo J, Wang C, Luo F, Yu X, Zhang W, et al. Clinical characteristics and intrauterine vertical transmission potential of COVID-19 infection in nine pregnant women: a retrospective review of medical records. The Lancet. 2020;395(10226):809-15.

2. Schwartz DA. An Analysis of 38 Pregnant Women with COVID-19, Their Newborn Infants, and MaternalFetal Transmission of SARS-CoV-2: Maternal Coronavirus Infections and Pregnancy Outcomes. Archives of Pathology \& Laboratory Medicine. 2020.

3. Dong L, Tian J, He S, Zhu C, Wang J, Liu C, et al. Possible Vertical Transmission of SARS-CoV-2 From an Infected Mother to Her Newborn. JAMA. 2020.

4. Wang S, Guo L, Chen L, Liu W, Cao Y, Zhang J, et al. A case report of neonatal COVID-19 infection in China. Clinical Infectious Diseases. 2020.

5. Racine R, Winslow GM. IgM in microbial infections: taken for granted? Immunology letters. 2009;125(2):7985.

Table 1. Laboratory and imaging findings of the neonate
Table 1. Laboratory and imaging findings of the neonate

Laboratory and imaging tests
Table 1. Laboratory and imaging findings of the neonate

Results
Table 1. Laboratory and imaging findings of the neonate 


\begin{tabular}{|c|c|c|c|}
\hline $\begin{array}{l}\text { Table } 1 \text {. Laboratory } \\
\text { and imaging findings of } \\
\text { the neonate }\end{array}$ & $\begin{array}{l}\text { Table } 1 \text {. Laboratory } \\
\text { and imaging findings of } \\
\text { the neonate }\end{array}$ & $\begin{array}{l}\text { Table } 1 \text {. Laboratory } \\
\text { and imaging findings of } \\
\text { the neonate }\end{array}$ & $\begin{array}{l}\text { Table } 1 \text {. Laboratory } \\
\text { and imaging findings of } \\
\text { the neonate }\end{array}$ \\
\hline \multirow[t]{9}{*}{ 7-Mar } & $\begin{array}{l}\text { White blood cell count } \\
\left(\times 10^{9} \text { cells per } \mathrm{L}\right.\end{array}$ & 26.09 & $3.50-9.50$ \\
\hline & Neutrophil & 19.72 & $1.8-6.30$ \\
\hline & Neutrophil (\%) & 75.7 & $40-75 \%$ \\
\hline & $\begin{array}{l}\text { Lymphocyte count } \\
\left(\times 10^{9} \text { cells per } \mathrm{L}\right)\end{array}$ & 3.81 & $1.1-3.2$ \\
\hline & Lymphocyte count (\%) & 14.60 & $20-50 \%$ \\
\hline & $\begin{array}{l}\text { Red blood cell } \\
\left(\times 10^{12} \text { cells per } \mathrm{L}\right)\end{array}$ & 5.34 & $4.30-5.80$ \\
\hline & hemoglobin(g/L) & 179 & $130-175$ \\
\hline & $\mathrm{CRP}(\mathrm{mg} / \mathrm{L})$ & 1.65 & $<4$ \\
\hline & Chest CT & $\begin{array}{l}\text { bilateral pulmonary } \\
\text { interstitial emphysemas }\end{array}$ & $\begin{array}{l}\text { bilateral pulmonary } \\
\text { interstitial emphysemas }\end{array}$ \\
\hline 8-Mar & $\begin{array}{l}\text { RT-PCR for } \\
\text { oropharyngeal swab }\end{array}$ & negative & \\
\hline 9-Mar & $\begin{array}{l}\text { RT-PCR for } \\
\text { oropharyngeal swab }\end{array}$ & negative & \\
\hline \multirow[t]{3}{*}{ 10-Mar } & $\begin{array}{l}\text { RT-PCR for } \\
\text { oropharyngeal swab }\end{array}$ & negative & \\
\hline & $\begin{array}{l}\text { Anti-SARS-CoV-2 } \\
\operatorname{IgM}(\mathrm{AU} / \mathrm{ml})\end{array}$ & 19.26 & $<10$ \\
\hline & $\begin{array}{l}\text { Anti-SARS-CoV-2 } \\
\operatorname{IgG}(\mathrm{AU} / \mathrm{ml})\end{array}$ & 107.88 & $<10$ \\
\hline 14-Mar & Chest CT & $\begin{array}{l}\text { thickened lung texture } \\
\text { with no other } \\
\text { abnormalities }\end{array}$ & $\begin{array}{l}\text { thickened lung texture } \\
\text { with no other } \\
\text { abnormalities }\end{array}$ \\
\hline \multirow[t]{2}{*}{ 24-Mar } & $\begin{array}{l}\text { Anti-SARS-CoV-2 } \\
\operatorname{IgM}(\mathrm{AU} / \mathrm{ml})\end{array}$ & 6.71 & $<10$ \\
\hline & $\begin{array}{l}\text { Anti-SARS-CoV-2 } \\
\operatorname{IgG}(\mathrm{AU} / \mathrm{ml})\end{array}$ & 100.91 & $<10$ \\
\hline
\end{tabular}

